\title{
Anatomy of Nigerian Federalism: A Reflection of the Nagging Challenges and Prospects from A Cultural Relativist Perspective
}

\author{
Chioke, Stephen Chinedu ${ }^{*}$
}

\begin{abstract}
There is a dearth of reliable literature that appropriately coined and conveyed the conceptual framework of federalism, scarcity of reliable information that analytically $x$-rayed the structural arrangement of Nigerian federalism, and challenges militating against the expected gains of federalism and the prospects thereof. The paper relied on qualitative methods like document analyses, personal experiences, key informant interviews, and discussions in generating relevant data that were thematically presented and resultantly analyzed using content analysis. The results show that there are works of literature that wrongly conceptualized federalism. Police brutality, political godfatherism, corruption, secession, revenue allocation problem, sectionalism, and conflicts were among the predominant challenges facing Nigerian federalism. Furthermore, the results show that sustainable development and efficient service delivery are part of the prospects. The paper concluded that many Nigerians do not have an adequate understanding of the nitty-gritty of federalism. As a corollary to this, destructive tendencies have troubled Nigerian federalism, making the center epileptic. The study for policy and practice implies that Nigeria, the largest populated country of Africa, has continued its federalist operations on the side of very low cohesion and unification of existing ethnic groups.
\end{abstract}

Keywords: Anatomy, Cultural Relativism, Nigerian Federalism, Stomach Infrastructure, Democracy

\section{Introduction}

This paper titled anatomy of Nigerian federalism: a reflection of the nagging challenges and prospects from a cultural relativist perspective, tilted toward reviewing existing literature on federalism. Hence, this underscores the empirical significance of the title and the entire work. On the theoretical significance of this review, it is the expectation of the author that this paper will be additional literature with a difference from the existing literature that focused on federalism. However, this present paper will provide succor to navigating through conceptual analysis of federalism in Nigeria. It is also an attempt to reposition the ailing federal system of government in Nigeria by chatting the way forward through its recommendations.

\footnotetext{
* Nnamdi Azikiwe University, Awka, Nigeria. Email: eruditescholar001@gmail.com
} 


\section{PanAfrican Journal of Governance and Development, Vol. 2, No. 2, August 2021}

Presently, Nigeria is a great nation-state, greatly endowed with unimaginable resources. To say that Nigeria is materially endowed is not erroneous. To suggest that Nigeria is humanly blessed is equally not an overstatement. Nevertheless, to say that the center and the rest of the component units are poorly managed is by no means an understatement. Then what is the nagging challenge? It is the over-concentration of power at the federal level, reckless abandonment of social responsibilities by corporate bodies, the culture of looting - gaining wealth illicitly by a public official and allied matters. It then becomes pertinent to ask: why is Nigeria called the Federal Republic? According to Oboli (1965, p.13), "Nigeria is called the Federal Republic of Nigeria for two reasons:

a) Nigeria is a Republic. This means that it is governed by persons who have been elected by the people of Nigeria, and the head of the state is the president.

b) Nigeria is a federation: This means that it is made up of several regions, each of which has its own government and some control over its regional affairs."

In line with the number (b) above, we note that Nigeria has replaced that term (regions) with geopolitical zones and regional states. Hence, the researcher herein adopts states/geopolitical zones for the purpose of this analysis. Arguing from the (b) reason above, we would point out that the component states in Nigeria are merely toothless bulldogs that cannot bite, and in the present ordeal, they are powerless appendages uniquely contrived and affixed to the center. This contributes to making Nigeria's federalism a sort of feeding bottle federalism. "Suffice it to say that the very unprecedented odoriferous saga that has saturated and permeated the federal government, political thoughts, political lifestyle, game, and social engineering in the ever dynamic sovereign entity, Nigeria is obviously and intricately enigmatic in its totality even when the economic and political policies of the state have been transfigured by the change in the bureaucratic template of Nigeria (Chioke, 2017, p.3)." The states/geopolitical zones in Nigeria are slaves benefitting from the crumbs that fall from the table of the master - the government at the center.

Given this, the states are beggars at the mercy of the troublers of Nigeria, the corrupt ruling and non-ruling elites. We are where we are today because the leaders pretend to be working when they are merely moping with utter confusion at the constitutional duties that premised the social contract the state and her citizens entered into, which resultantly gave rise to an entity called Nigeria. However, did the generality of the country bargain for such a Nigeria with her peculiar 
Chioke, Stephen Chinedu, Anatomy of Nigerian Federalism: A Reflection of...

federalist structure? Many believe that the response to this query is a 'no' answer. We, therefore, recognize that there abound countless challenges that have contributed to the failure of the Nigerian style of federalism. Amongst them is greediness occasioned by the stomach infrastructure of the whole members of the general system called Nigeria. According to Dauda (2020, p.366), "Stomach infrastructure is a reality projected by the Nigerian politicians on the vulnerable electorate who for poverty are encouraged to mortgage their fundamental right of freedom to choose who governs them in exchange for immediate gratification in monetary, food, or other material terms." The politics of the now and not of the later negates good governance and sustainable development and embraces perishable commodities for immediate consumption and future servitude/hunger.

There are responsibilities, functions, and duties enshrined in the federal government's exclusive list because of the nature of those functions. Sequel explained that "The Federal Government retains those powers, e.g., defense, foreign affairs, and communications, which are essential for the unity of the Federation (Oboli, 1965, p.13)." To buttress this, we may recall that the National Open University of Nigeria (NOUN) (2014) aligned in this way: "Some authors see federalism as a form of governmental and institutional structure put in place for the purpose of maintaining unity while also preserving diversity (p.99)." We emphasized the term 'unity' to show the need for federalism. However, it is quite regrettable to note that the federal structure has hosted centrifugal forces, which have often threatened the unity of Nigeria. For the adequate performance of the existing contractual responsibilities, the constitution accorded the central government these functions enlisted in the exclusive list, but the nagging challenges have remained detrimental and have sabotaged the attainment of sustainable national development. Let us bear in mind that "Government is the machinery of the state through which the wills and aspirations of the people are articulated, crystallized and implemented (Ewuim, 2008, p.iii).”

Nigeria is far from achieving the wills and aspirations already articulated through her stance on the federal system of government and factors like poor implementation of policies and lack of true federalism rooted in democratic leadership. Then the other factor is one of the principal concerns of this paper, summarily called the challenges of Nigerian federalism. To clear the intellectual underbrush that has engineered and helped in obfuscating roadmaps to where we ought to stand at this point and the ongoing controversies regarding the true meaning of 


\section{PanAfrican Journal of Governance and Development, Vol. 2, No. 2, August 2021}

federalism explicitly encoded in the available literature. Therefore, this paper would first and foremost throw up introductory remarks on the meaning of federalism and present Nigerian federalism from a cultural perspective. Specifically, it is poised to examine and bring to the fore the challenges and prospects of Nigerian federalism from a cultural relativist point of view because it is a formal statement of history that the community's or the people's challenges must be addressed from the angle of their cosmology. Hence, the cultural relativist dimension appears to be helpful in addressing the nagging challenges of Nigerian federalism.

\section{Statement of the Problem}

The author had observed the poor knowledge of students and practitioners on the subject matter undertaken by this review. Arguably, this problem emanates from the existing literature that had introduced and inculcated this poor knowledge via its poor conceptual explication. For example, commenting on the component units of a federation, Ewuim (2008, p.72) posited that, "These components may be the central, state (regions) and the local (counties) governments." Additionally, there is a paucity of literature that appropriately coined and conveyed federalism from a glocalized purview. Hence, the need to relay useful impulses that guide students' conceptual knowledge and understanding of federalism and the poorly educated mass of politicians in the system.

There appears to be a dearth of literature that analytically pointed out the structural arrangement of Nigerian federalism. From careful observation, there is a probability that federalism has been practiced without due consideration to the unique cultural patterns of Nigeria as a sovereign entity, which has resulted in a sort of marriage of inconvenience. Concerning this, the article will seek to dissect the anatomy of Nigerian federalism from a cultural relativist background to show the various centrifugal inputs that have troubled the structure of federalism in Nigeria.

Despite the workability and dividends of federalism in other climes, there seem to be in existence copious negative trends in the political-institutional machinery and the general administration of Nigeria. Perhaps, these include nepotism, godfatherism, corruption, maladministration, and others. These may have contributed to fueling dissenting voices with respect to Nigeria's existence as an indivisible sovereign state. Therefore, another problem of this study is to x-ray the web of challenges that have disturbed federalism in Nigeria.

\section{Objectives of the Paper}


Chioke, Stephen Chinedu, Anatomy of Nigerian Federalism: A Reflection of...

The broad objective of this paper is to present the anatomy of Nigerian federalism: a reflection of the nagging challenges and prospects from a cultural relativist perspective. To achieve this, the following specific cardinal objectives guided the review: i) To relay useful impulses/phraseologies that will aid proper conceptual knowledge and understanding of Nigerian federalism, ii) To carry out a dissection of the anatomy of Nigerian federalism from a cultural relativist background, and iii) To examine and bring to the fore the challenges and prospects of Nigerian federalism from a cultural relativist approach.

\section{Theoretical Standpoint}

Cultural relativism is herein adopted as the paper's theoretical foundation. Cultural relativism is a theory that propagates or projects consciousness of differences in existing cultures all over the globe. "Cultural relativism is a complex concept that has its intellectual roots in discussions about relativism in the philosophy of science and the philosophy of language. Relativism is typically viewed in contrast to realism, which is the idea that what is true and real exists independently of the mind (Idike, 2014, p.5)." Put differently, "The perception that the norms and values of each culture have their own validity and cannot be used as a standard for evaluating other cultures is termed cultural relativism (Okafor \& Emeka, 2004, p.21)." Cultural relativism projects the idea that a specific culture should not be used as a yardstick to measure or pass judgment on any other culture. In this regard, no one culture is superior to another compared to cultural practices, politics, laws, mores, ethics, besides others. Thus, culture is indeed relative. Nigeria, as a political unit, has its political culture with its own peculiarities. Then to understand federalism, we embark on it from the lens of cultural relativism, hence Nigerian federalism. Why say Nigerian federalism? This is simply because this sort of federalism is as practiced in Nigeria with or without the exact trappings of federalism obtainable in other climes.

Writing further, Okafor \& Emeka (2004, p.21) stated, "This perception recognizes that what is weighty in one society may be trivial in another and that each trait has full validity within its own cultural environment and must be respected as endowing itself with its own validity." Therefore, "It is impossible to understand the behavior patterns of other people if the criterion for acceptance or rejection is solely what happens in our own (Ibid)." Then, one would say that cultural relativism is advantageous as it fashions fathomable dimensions for appreciating the need for equality, respect, fairness, and tolerance for the totality of the way of life of other 


\section{PanAfrican Journal of Governance and Development, Vol. 2, No. 2, August 2021}

people, tribes, races, groups, and entities. It is hundred percent possible and even entirely true that one's experience of a system of doing things and in our present case, federalism will and must not necessarily be the same with the other(s). Perhaps, it was in line with this that Okafor \& Emeka $(2004$, p.21) opined that "...cultural relativism gives room for varieties, tolerance and respect for the way of others." Owing to this, cultural relativism is repugnant to ethnocentrism in all aspects. In this dimension, there is a need to reject the idea of an absolute method or viewpoint based on one's own culture, which appears to be the epicenter of ethnocentrism. This helps us to understand the peculiarities and unique differentia observable in Nigeria's typology of federalism. We know the Nigerian federalism is not the same as what is practiced and obtainable in other developed democracies of the world.

From the angle of cultural relativism, this study examines how federalism, as practiced in Nigeria, is different from what is obtainable in developed federalist states of the world. To apply the cultural relativist approach to this paper, it is thus borne in mind that what works for one or other regional or sub-regional cultural cum political enclave(s) in the adoption of a federal system of government may not work for Nigeria because of the differences in cultures and traditions. No doubt, people's experiences differ in size and weight, and in the same vein, a country's experience with respect to policies and activities is not entirely similar when viewed from the experiential evidence in other countries. The reason is that human beings are not scientific, and that makes public administration a cumbersome activity.

\section{Materials and Methods}

A qualitative research method was adopted. Creswell (1998) advocates 20 - 30 samples for qualitative research. Thus, secondary data collected through a thorough review of textbooks, journal articles, and internet sources have been analyzed qualitatively. In order to complement and authenticate the views expressed in the extant literature that made up the secondary sources of data, the researcher employed the use of Key Informant Interviews (KIIs). The informants include 5 Secondary School Students, 5 Undergraduates, 5 Public Administrators, and 5 Political Scientists from the component units in Nigeria. The interviewed Key Informants (KIs) and their respective disciplines for each scholar are abbreviated as secondary school students (SS), undergraduates (UG), and public administrators (PA), while 1, 2, 3... was used to differentiate the thoughts of informants from the same discipline.

\section{Results and Discussion}


Chioke, Stephen Chinedu, Anatomy of Nigerian Federalism: A Reflection of...

This section deals with a detailed presentation and discussion of the findings vis-à-vis the specific objectives of this review. From a content analysis cum descriptive method, the author relays the following findings on the specific objectives of this paper:

\section{Federalism: An Analysis of the True Meaning from a Glocalized Viewpoint}

By assumption, almost everyone is quite familiar with the concepts - 'federal government and federalism' as they are now household phraseologies employed in daily chats and discourse. However, we cannot rely on such a level of familiarity to conclude that all know these concepts and then hastily conclude that such knowledge is adequate to be adopted as a foundation for an acceptable or classical definition and practice of federalist governance. First, to duly decipher and appreciate this scholarly attempt, the scholars must remember that the terms 'federalism' and 'federal system of government' are the same and thus used interchangeably in this study. Having said this, we then note that "Federalism is a system of government in which governmental powers of a given state is constitutionally shared between the Federal Government and other component units. In Nigeria's federalism, powers are constitutionally shared between the federal government and federating units - the states. Here, each level of government enjoys a certain degree of autonomy. By virtue of federalism, it suffices to say that the federal government and the federating units are contractually bound for purposes explicitly or implicitly underscored (Chioke, n.d, p.171)."

Apart from Nigeria, we have other examples of countries with a federal constitution, such as the USA, Argentina, and others. Put differently, Maduabum (2008), cited in NOUN (2014, p.99), opined that, "Federalism is a political concept in which a group or member is bound together by covenant with a governing representative head." These two definitions have something in common and adequately show that there is always a bond between the center and other units. Why? They are bound together for one reason or the other. Nevertheless, these conceptual reviews are not enough to be adopted herein as this paper's operational definition of federalism.

In keeping with the already highlighted problem statement, Akpotor $(1995$, p.8) defined it as "the system of government in which governmental parts are shared between the central government, 
PanAfrican Journal of Governance and Development, Vol. 2, No. 2, August 2021

i.e., the federal government and its components (State and local government)." In this regard, the following informants stated:

\begin{tabular}{|l|l|l|}
\hline Code & Institution & Remark \\
\hline (KI: SS) & Community Secondary School & $\begin{array}{l}\text { Federalism is about the } \\
\text { sharing of power between } \\
\text { the central government, } \\
\text { state, and local government. }\end{array}$ \\
\hline (KI: UG) & Federal Polytechnic, Oko & $\begin{array}{l}\text { Federalism is a system of } \\
\text { government in which } \\
\text { governmental powers are } \\
\text { constitutionally shared } \\
\text { between the levels of } \\
\text { government (federal, state, } \\
\text { and local government). }\end{array}$ \\
\hline (KI: PA3) & $\begin{array}{l}\text { Federalism is a system of } \\
\text { government where power is } \\
\text { shared among the three tiers } \\
\text { of government viz } \\
\text { executive, legislature, and } \\
\text { judiciary }\end{array}$ \\
\hline
\end{tabular}

Following these misconceptions, two questions arise below:

$>$ Our bodies like the executive, legislature, and judiciary tiers of government or arms of government?

$>$ Does the local government really possess and enjoy the constitutional power that makes it to be seen as a federating partner in a federation?

For the first question, these bodies are known as arms/organs of government. Then for the second question, we note that the answer is no when viewed from both international and contextual purview. Contributing to the existing misconceptions about the meaning of federalism, it was stated that, "Federalism is a system of government in which the powers of the state are divided among the various tiers, levels or components that make up the state. In it, both the taxing and expenditure powers of the state are shared among the components of the federation. These components may be the central, state (regions) and the local (counties) governments (Ewuim, 2008, p.72)." Consequently, Amah (2017, p.288) noted that "Federalism as a political arrangement has faced serious crises of conceptualization."

Following the logic of the above perspectives, the paper, therefore, submits that the views expressed therein are wanton in practice, universality, acceptability, and credibility. Thus, these definitions should not be accepted as proper conceptual explications. Why this stance? It is 
Chioke, Stephen Chinedu, Anatomy of Nigerian Federalism: A Reflection of...

popularly believed that it takes two to tangle. When viewed from a global lens, the federal system of government presupposes a system of government in which powers are shared between the federal/central government and states without further justification. In this parallax, local government or counties or whatever lesser name may be given, any government lower than the state is not a federating unit because it is unknown to the constitution as a sound federating unit. Categorically, those governments at the grassroots (local governments) are just administrative units, whereas the States are federating units.

Based on these propositions, this current study does not subscribe to Akpotor (1995), Ewuim (2008), and other perspectives that erroneously inputted local government as a federating unit, because it is practically evident within our territorial jurisdiction and other world-known federal States that local government is not recognized as a federating unit. Local governments are merely recognized in the 1999 Constitution of the Federal Republic of Nigeria as the third tier. However, are they the third-tier government in the true sense of a federating partner or any ramifications such as fiscal autonomy? As acknowledged by one of the informants, "Federalism is a system of administration/government made up of a central authority and constituent parts with the bulk of the power residing at the center (KI: PA2)."

A Constitution Lawyer, Prof. Itse Sagay, was quoted in The Nation Newspaper, "Those advocating autonomy for local government should bid federalism goodbye." It is apparent that there is no known provision for local government as a federating unit within Nigeria's democracy and other developed democracies of the globe and to think or talk of such is to engage in frivolity, absurdity, and vanity of the highest order. In a federal system, powers are shared between states and a central governing authority having postulated nationwide, sub-regional wide, regional wide or worldwide duties vested on it by the electorate through the instrumentality of the grundnorm, international conventions, and treaties. At the central level, these powers are simply the exclusive list of the federal system of government which is usually reserved and left for the central authority. The residual list is the legislative powers of the State governments in Nigerian federalism.

In line with the specific objective, we contextualize and operationalize federalism as follows:

a) In any sound sovereign state, federalism is a process as well as an established structure of governance that develops and fosters unity in diversity on the basis of mutual 


\section{PanAfrican Journal of Governance and Development, Vol. 2, No. 2, August 2021}

agreement by constitutionally uniting politically stratified and disjointed units (i.e., states as a federating partner) into a limited, but encompassing political system known as a federation. Given this, federalism as a process is to install appropriate mechanisms and apparatuses for attaining the will of the state through public administration. As a structure, federalism is structurally contrived to manage and juxtapose sensitive matters unavoidably needed to maintaining unity amidst the need to preserving diversity and heterogeneity.

b) Nigerian federalism is a system of governance/public administration where political powers are constitutionally shared between the federal government and the federating units. However, it must be borne in mind that each level of government in Nigeria enjoys a certain degree of autonomy, but the irony here is that the autonomy and discretion given to the government at the center is too much when compared to other known federations like the United States of America (USA). As such, it takes to tangle any inclusion of another body as a federating partner creates a power imbalance and would further degenerate into unequal yoking and crises.

Summarily, these definitions represent a glocalized perspective on the conceptual demystification of federalism against the doctored and contorted views of some authors of textbooks used in teaching and coaching naïve and unsuspecting learners in Nigeria and possibly beyond.

\section{Nigerian Federalism: A Dissection of the Anatomy from a Cultural Perspective}

Anatomy is a branch of natural science that deals with the structural organization of living things. Though anatomy is a scientific term that means the scientific study of the structure of animals and human bodies, it is herein used to dissect and show the components of Nigerian federalism inherent in the organizational structures and state apparatuses. This would enable juxtaposing various centrifugal issues that bother on the federal system of government as perceived by Nigerian elites (ruling and non-ruling elites inclusive) and the generality of the electorate.

To show the matter, it is herein stated that Nigerian politics, leadership, democracy, and federalism are deeply rooted in stomach infrastructure. Stomach infrastructure peculiar to Nigerian politics is a concentration of political interest based on what is obtainable now that is 
Chioke, Stephen Chinedu, Anatomy of Nigerian Federalism: A Reflection of...

perishable in nature that was promised and made available for the immediate gratification of the belly than that which will make the future better sustainable. In short, this is politics based on the immediate provision of perishable goods for the immediate gratification of the poor electorates. What is the impact of this on the development of electioneering processes in Africa with a specific emphasis on Nigeria? Perhaps, this is a gap that other empirical studies by the interested researcher may consider to fill in subsequent attempts.

Imperatively, to say that stomach infrastructure has become the culture of virtually the masses educated and illiterate is not an aberration. The educated engage in the immediate gratification of the stomach and selfish desire during pre-election and election period due to unemployment and underemployment/meager earnings. The illiterates do that on the ground of ignorance of the fact that they are directly or indirectly mortgaging their future and that of their children in the hands of enemies of their sustainable progress.

At this juncture, we hasten to add that the culture of stomach infrastructure has challenged Nigerian federalism, and everyone seems to be focused on the present satisfaction of human needs, especially food. As most electorates are in dire need of food, politics here is based on who promises to give/serve the people food. In reality, the food served has always been in the manner of crumbs. Crumbs are traditionally the exclusive reserves of dogs and slaves. Hence the colonial masters had seen the blacks in Africa with the core emphasis on Nigeria as slaves and dogs. They positioned for the devouring of crumbs that fell from the table of the indecent master. The emphasis here is that Nigerians were reduced to glorified slaves as did by the British colonial authorities and the leaders who directly or indirectly siphoned Nigeria and Africa at large.

There is no gainsaying that Nigeria is a sort of colonial embargo placed upon people from various tribes who from the onset did not bargain for amalgamation of the present sort partly because of the vivid satisfaction ostensibly derived from their existing political arrangements. To say that all the tribes in Nigeria had one form of government or the other is by no means an error. We are duly informed about the existing government in various parts of Nigeria before the coming of the White with their ulterior motives. For example, “...the territory contained a number of people, each severally pursuing its own destiny. Each of these peoples had achieved or succeeded, through varying degrees, in developing their own peculiar civilization so much so that what the European colonizers encountered on arrival were several independent political 


\section{PanAfrican Journal of Governance and Development, Vol. 2, No. 2, August 2021}

units, some considerably highly developed, and others very simple. Generally, each remained politically distinct and separate (Udenta, 2004, p.350)." To further back up the preceding views, we project Ojukwu's claims as follows:

These tribes, though variedly associated with the three major entities, still preserved their independence and pursued their progress, each in a manner quite distinct. Each also had developed sophisticated cultures of renown, chronicled in the annals of international history long before the birth of Nigeria and some of these ancient groups include the Edos of the Mid-West, the Ijaws of the Delta, the Kanuri of the North-East (an offshoot of the ancient Songhai Empire), the Jukuns of the Middle Belt, and the Nupes, just to mention a few (Ojukwu, 1989, p.15).

Indeed, Nigeria was contrived by the British colonial imperialist for the purpose of siphoning the wealth of Africa. Corroborating this, a Bureaucrat in an interview with the author, when asked do you think the British colonized Nigeria for the purpose of siphoning the wealth of Africa? He answered in affirmative as:

Before the name Nigeria came to be, it has been existing till the amalgamation of Northern and Southern protectorate in 1914. This would have brought the people together and provided a firm basis for the arduous task of establishing closer cultural, social, religious, and linguistic ties, which are vital for true unity. For the colonial masters, this union, if allowed to develop, would have amounted to a major threat to the very economic interests they were striving to protect. This brought about the system of divide and rule government in the country. This also brought about social apartheid, division, hatred, unhealthy rivalry, and pronounced development disparity among the country's various people (KI: PA1).

Then, it is not an error for one to say that Nigeria was born as a result of corruption and into severe corruption originated from her corrupt parents. Under this colonial background, the angle of culture would be appropriate to investigate the problems under investigation. That is, we begin by excavating and presenting the meaning of culture. "A very natural approach to the study of any culture is to describe the way the people perceive their world (Kalu, 1978, p.37)." This suggests that culture is based on the way people perceive their world and not just merely about 
Chioke, Stephen Chinedu, Anatomy of Nigerian Federalism: A Reflection of...

how they perceive it, but how they react to various stimuli, elements, and forces that symbiotically or parasitically interplay in their physical and social environments.

To Udenta (2004, p.347), "... culture is the concept or notion that stands for a network of designs, prescriptions, and responses, both existential and normative, which characterizes a designated aggregate of people." To this end, what is the people's perception as per the federalist structure in Nigeria? On the side of the meaning of perception, Udenta (2004, p.348) wrote: "perception is the process by which we organize and interpret the stimuli in our environment." Therefore, Nigerians' perceptions as per federalism are nostalgic and, to a high extent, deeply rooted in regrets. For instance, with respect to Nigeria's federalism and public administration, there are two observable stimuli in her public space: negative and positive. The negative stimuli are the challenges of Nigerian federalism, while the positive stimuli are the prospects. We shall look into these as we progress.

Still, on the nostalgic cum regrettable side of the present system, we note that Africa is the home of the black man. However, by deliberate exaggeration and miscalculation, Nigeria has been called/nicknamed the giant of Africa. If Nigeria is the giant of Africa, simple logic thus tells us that Nigeria should be the home of the black man the world over. In reality, with her quasifederalist position, Nigeria is a political entity under the neocolonial rulership and influence of those she should ordinarily be better than if not for the existing marriage of inconvenience. Therefore, one could testify that Nigerian federalism is soaked with colonial mentality and shape, Shibboleths, Manichaeism, and anti-corruptionist philosophy with its evident utopian approach.

Hence, the entire polity is wallowing in seemingly inextricable corrupted federalism that we can now refer to our poverty of idea/practice as quasi-federalism. We cannot thence say we are unaware of the dangers thereof. In this sense, to state and demonstrate the true meaning of Nigerian federalism, we examine the views of other citizens - that is what is obtainable in Nigeria. Then, "To begin with, Shibboleths and Manichaeism speak of a Weltanschauung or world-view enmeshed in stereotypes, straight jackets, jaundice or prejudices" (Udenta, 2004, p.347).

By this, we see the big ordeal that has eaten deep into the fabrics of Nigeria's cake-sharing methodology, ideology, and culture. The methodology, ideology, and culture in the county's 


\section{PanAfrican Journal of Governance and Development, Vol. 2, No. 2, August 2021}

resource allocation are deeply embedded in prejudice exhibited through tribal sentiments and the utter discard of the so-called federal character principle by the government at the top echelon and even those below. At this point, we hasten to add that Nigerian federalism is a federal structure created and luridly decorated with such elements as falsehood, mismanagement, injustice, too much concentration of power on the center, meddlesomeness by the federal government on election matters at the federating partners' level. In addition, divide and rule, quackery (unprofessionalism), disunity, unemployment, poor service delivery, and hatred against one another are rampant. These prevalent cultures have greeted Nigerian federalism, and these adverse inputs already pointed out above ought to be expelled in toto with immediate effect. With these, we now move correctly into the challenges.

\section{Cultural Relativist Presentation of the Challenges and Prospects of Nigerian Federalism}

Significantly, "The transformation and centralization of the Nigerian federation by "soldiers and oil' has produced contentious and contradictory outcomes (Rotimi, 2010, p.459)." It is enough to say that Nigerian federalism is enveloped in diverse challenges that have threatened the coexistence of all and sundry. Perhaps, it is against this backdrop that Rotimi (2010, p.459) pointed out that, "Many influential commentators describe the current centralized system of federalism as a veritable source of, rather than a credible solvent for, the country's multifaceted crises of unity (emphasis mine), democracy and development." Reacting to the question - while asked to give an opinion on Nigerian federalism? An interviewee retorted, "With the recent happenings, Nigerian federalism is not encouraging at all. It is more of anarchy! We wish for a change - God should send Nigeria another David." At present, certain features in the form of irregularities and challenges have become a stumbling block to the actualization of true federalism in Nigeria's polity vis-à-vis the behavioral/cultural patterns of the heterogeneous nationalities in Nigeria. Thus, these challenges are relative to Nigeria as a sovereign entity, which means that those spotted challenges may not be the problem of other known federations in Africa and the world. They are:

Police Brutality - The Nigerian Police Force seems to have been socialized with extreme measures of brutality, and this has permeated the public space without an express permit. As such, many, including the author, have endured a measure of brutality from the Nigerian police force in one form or the other. The recent \#END SARS protests all over the country speak volumes of this challenge and have equally painted the Nigerian Police Force with unacceptable 
Chioke, Stephen Chinedu, Anatomy of Nigerian Federalism: A Reflection of...

(lurid) colors. Indeed, this has equally made mockery of her federalism and democracy. Looking at police brutality, do we think it has scorned federalism and governance in Nigeria? An interviewee reacting to this question said: "It has undermined everything we know about federalism, for police brutality is one-sided going by what we observed so far in Nigeria (KI: PA1)." He went further to say, "It is what led to the past anti-SARS protests. Our president behaved like a feudal potentate, demonstrably unconcerned and dangerously clueless (KI: PA1)." It can be said that Nigerian Police Force is a puppet under the manipulation and control of the federal government to the detriment of federating units is quite acceptable and in order. However, regrettable is the underlying aftermaths in our anarchy-riddled and ridden society.

Minority Issue and State Creation - There have been several calls for the creation of another state, particularly in the Eastern part of Nigeria. Ethnic multiplicity led to the development of ethnic nationalism in Nigeria, leading to increased demand for autonomy (Chioke, n.d). Minority issues have lingered in Nigeria even before October 1, 1960, Independence. It is in response to minority issues that the Colonial Administration in 1957 set up Willink's Commission. The Commission was charged with the task of conducting an inquiry into the fears of minorities and the means of allaying those issues. In its report, Willink's Commission, after various meetings and hearings of the complaints and submissions on the way forward, did provide the Colonial Administration with a detailed view and comprehension of the nature and scope of the fears of the minority tribes from Northern and Southern protectorates of Nigeria. Nevertheless, the fears of the marginalized minorities in Nigeria are left unattended to and in the southeast geopolitical zone, the matter over these years has been the issue of creation of one additional state, which has equally been recklessly allowed to culminate into dangerous agitations for the secession of the Igbo nation, known as Biafra. In respect of minority issues, it led to the cataclysm and genocide experienced in Eastern Nigeria during the three-year war of 1967 - 1970.

Political Godfatherism - Politics, according to Chikendu (2002), "is that aspect of human activity which deals with the distribution of power, influence, and authority in the state for the purpose of order and good government." In lieu of the fact that politics is about the distribution of power and authority in the state for the purpose of order and good governance, it must be stated herein that political godfatherism has over the years been wrongly used to arrogate political power and authority to a few non-ruling elites (godfathers) in the states/federation and 


\section{PanAfrican Journal of Governance and Development, Vol. 2, No. 2, August 2021}

this has posed a heavy stooge to federalism in Nigeria. For instance, Mgbenkemdi (2015) argues that "In the Nigerian society today, the one who is regarded as a godfather is expected to service the inordinate ambitions of his wards (p.10)." To further demonstrate the challenge of Nigerian federalism in keeping with political godfatherism, it is reiterated that:

"Importantly, political godfatherism, just like corruption, throws up goal displacement and this has plagued the general interest of state. Political godfathers usually form political coalitions in order to capture the political apparatus of the state and attendant maintain a monopoly of political power. And this, more often than not, is perpetuated in a sit tight political setting with the intention of dictating the tune of state politics and equally determining who gets what, where, and how in the bureaucratic setting. This does not augur well with sustainable development in Nigerian politics and Enugu State in particular because the goal of the state having been displaced leaves the state with nothing for sustainable development" (Chioke, 2020a, p.287-288).

Indeed, godfatherism has threatened the federalist structure obtainable in Nigeria and has widened the gap between the haves and the have not.

Boundary Disputes - The problem of intrastate boundary disputes is a major hiccup to federalism. For instance, the problem of a land dispute between Ezza and Ezillo in Ebonyi State is the locus classicus of this issue, and it has resulted in a wanton rate of loss of lives and property (Chioke, n.d). Also, there are instances of boundary disputes between some parts of Ebonyi State and Cross River State, and the two-state governments seem to have joked with the management of the clashes between one community and another. Thus, boundary disputes have brought the worrisome cumulative effect of decreased gross domestic product (GDP) and per capita income via wanton loss of lives and mass destruction of properties during communal clashes related to land matters. The problem of boundary disputes is an indication of the failure of government at the state and federal levels.

The terminal disease called, Corruption - It is an understatement to say that corruption is not a disease and not an exaggeration to aver that it is a terminal disease. Corruption is worse than bacteria. It is a phage and must be shown the exit door. Sapru (2013, p.506) argues that "Corruption clearly entails increased administrative costs, losses in government revenue, and 
Chioke, Stephen Chinedu, Anatomy of Nigerian Federalism: A Reflection of...

makes administration difficult as it creates a second line of authority parallel to the formal one, in the process undermining and weakening it." Thus, “... without mincing words, the issue lies in the nation's inability to pass the subtle line of the nation's childhood threat - Corruption (Chioke, 2016, p.1)." Sen Babafemi Ojudu, in a plenary session on December 20, 2012, warned that "If you don't kill corruption in this country, corruption will kill all of us." For this reason, "...virtually all the Nigerian leaders who have come in as physicians have left office as a patient (Ilufoye, 2009, p.281)."

Issue of Secession - The secessionist trouble that swallowed Nigeria's existentiality and potentialities could be traced to colonial times. The Eastern region of Nigeria has always felt dissatisfied over the divide and rule policy and ill-treatment meted out to them by the British's despotic colonial cum imperialistic rulership. This paved the way for what transpired in the Legislative house - a motion for self-government in 1953. We note that "After the motion for self-government by Anthony Enahoro in 1953, there has been a secessionist struggle here and there in Nigeria, which contributed significantly to the challenges of Nigeria's federalism. The secessionist struggle started from the North when the motion for self-governance was made in the house. Then, the secession issue can also be traced to Yoruba's disagreement with the proposal to separate Lagos from the Western Region. The last was that of the Igbo's in 1967 when the Nigerian Biafran civil war eventually kicked off (Chioke, n.d, p.171)." Today, we have seen the birth and growth of several secessionist groups like MEND, MASSOB, and IPOB, all pushing for the disintegration of Nigeria.

Revenue Allocation problem - Regrettably, Heather (2011, p.62) opines that "Data from social indicators also demonstrate the lack of equal distribution of revenue allocation among levels of government." To this end, "The problem of equitable and accepted revenue allocation sharing formula has hampered the needed peaceful atmospheric condition for true federalism (Chioke, n.d)." The issue of revenue allocation has become a source of conflict between the center and other federating units. With this, leaders of different federating partners in Nigeria and the central government have struggled to manage the outpouring demands of managing poverty and have resorted to injecting the stomach infrastructure syndrome into Nigerian politics. 


\section{PanAfrican Journal of Governance and Development, Vol. 2, No. 2, August 2021}

It is evident that "In Nigeria, the politics of poverty and the poverty of politics seem to have coalesced to produce a phenomenon known as 'infrastructure of the stomach' in the polity (Dauda, 2020, p.366)." Moreover, every stakeholder in this federation seems to be hugely concerned and preoccupied with the means of salvaging the ever insatiable protruded stomach of the elites here and there. However, we must not forget that "Revenue allocation at the government level affects citizens through the quality and level (or lack of) societal infrastructure (Heather, 2011, p.62)."

Sectionalism and Favoritism - The current ebb and flow of sectional, religious and tribalistic disposition displayed by the Buhari's led administration is a serious threat to Nigeria's peace, unity, and federalist structure. Corroborating this, an interviewee reacted as "Nigeria is not a true federal state. Its power and profiling are one-sided. Why are some people untouchable? Why are some tribes being more favored? The problem is too complex to get rid of (KI: PA1)." Right from the inception of Buhari's civilian government, Nigeria has not been able to stand with oneness and practice true federalism. It has been a case of sectional politics and unjust allocation of values. Hence, the center cannot hold again! In the true sense, sectionalism breeds a dearth of qualified manpower in the organization of societies plagued by it.

To start with, "Organizations in the Nigerian context have suffered supply shortage, and this has remained an ugly reoccurring decimal in the nation's public enterprises and civil service, and one cannot, therefore, look askance at this and wallow in the pretense that all is well with the sovereign entity wrongly called the giant of Africa (Chioke \& Mbamalu, 2020, p.388-389)." It is thus unequivocally stated that "Effective bureaucratic leadership is missing in Nigeria's path to good governance and improved quality of life for her citizens (Ukeje, 2006, p.1)." Furthermore, the disappearances of effective bureaucratic leadership coupled with sectionalism/tribalism have hindered the practice of true federalism in Nigeria and likely beyond. As such, "Bureaucratic organizations in Nigeria are largely and grossly inefficient (Chioke, 2017, p.11).”

Conflicts - Conflicts are quite unavoidable in both human and institutional relationships. With respect to the institutional relationship, there are disagreements between the federal government and states in Nigeria. Also, there are examples of Executive - Legislative conflicts at the federal and state levels. Nevertheless, the question is: what are the causes of conflicts between these 
Chioke, Stephen Chinedu, Anatomy of Nigerian Federalism: A Reflection of...

institutional relationships? This is another gap where other researchers can investigate the deeprooted problem.

Then we pause to ask: why do conflicts occur between the above institutions? Now, conflict in the above institutional relationships may occur with respect to uncertainties in the functionalities of federating partners, which are occasioned by ambiguous provisions and legal lacuna. In this tune, Ewuim (2008, p.73-74) opined that "Conflict and clash of interest may arise especially between the central and states/regional government in discharging their concurrent functions." Suffice it to say that, "Ultimately, focused reforms, especially electoral and anti-corruption reforms, will be required to consolidate Nigeria's real successes in mitigating potentially disintegrative ethno-political conflicts (emphasis mine) and to assuage current agitations for the wholesale restructuring or dismantling of the federal system (Rotimi, 2010, p.459)." We, however, recall that "The Civil War did not resolve the National Question in Nigeria (Abdul, 2007, p.81)."

Therefore, conflicts have continued to resonate and constitute a significant hiccup in Nigeria's search for a proper federal structure. In Nigeria, conflicts between the federal and state governments endanger, hamper and even depreciate sound and sustainable policymaking and policy implementation. Consequently, clashes between the above units (federal and states) have constantly thrown up copious effects in the manner of poor political and socio-economic wellbeing of the generality of the common people of Nigeria. Thus, it is believed that "Nigeria's political system has continued to operate with minimum cohesion (Ola, 1995, p.7)."

After discussing the challenges posed by the peculiar federalist style of the Nigerian government, we move to highlight the traceable prospects of federalism in Nigeria. Whatever be the case, it has been intoned that "As with all federal systems, the Nigerian federal system is a dynamic system which changes with time (Ufot, 1991, p.191)." There are a series of areas that the federalist structure already installed has to consolidate within the nation's political space. We would be succinct in our quest to dissect those areas objectively. Consequently, we extrapolate the few areas of prospects which are:

Sustainable Development - Federalism is a step toward sustainable development at the center and the national level. Then, what is sustainable development? We begin pretty simply by few words on development. Rodney (1972) sees "development whether economic, political or social 


\section{PanAfrican Journal of Governance and Development, Vol. 2, No. 2, August 2021}

as both increase in output and changes in the technical and institutional arrangement by which it is produced." Udenta (2004, p.355) says, "Development captures the ability of man to subdue his biophysical and inter-human environment - making it serve his needs. It is the ability of man to unlock or transform the boundaries of nature locked up in the earth's surface and direct these at satisfying his needs and desires which continue to increase and to assume more and more complexity." Then again, we bear in mind that "... development is a multi-dimensional concept and in spite of the various conceptions, development is basically about the process of changes which lies around the spheres of societal life (Chioke, 2020b, p.52-53)." In this dimension, sustainable development is one whose changes lie around the spheres of societal life, which considers the present and the future.

Now, how does federalism trigger sustainable development? It does that by giving room for discretion and initiative. Highlighting the merits of federalism, Ewuim (2008, p.73) stated that, "It promotes initiative and development as the different units can initiate their own programs." To achieve sustainably developed federating units, the performance of functions must follow due process. In light of this, we ought to bear in mind that "Performance of tasks must not violate existing enabling laws and the constitution of the land. Legality would help to ensure that the actions of organizations are not rendered nullity and declared ultra vires by a court of competent jurisdiction (Chioke \& Mbamalu, 2020, p.393)." Based on already relayed premises, it is wise to note that sustainable development is a crucial prospect of Nigerian federalism, and Nigeria will be on her to sustainable development if corruption and other challenges are rooted out.

Efficient Service Delivery - The sharing of powers gives room for effectiveness and efficiency in the performance of functions (Chioke, n.d). Federalism anywhere in the world has the potential of providing for the people in a more accessible way. Through efficient service delivery, the people at the federating units would benefit from the government at the center. There are various voices heard and some suppressed by the federal government with respect to undelivered services. In short, while some services were provided, others were poorly provided, others were abandoned, and many were left unattended by policy implementers at the state levels. However, there is a high degree of prospects regarding service delivery, which Nigeria has no choice but to toe the path of efficient service delivery. 
Chioke, Stephen Chinedu, Anatomy of Nigerian Federalism: A Reflection of...

Restructuring - There are different calls from all quarters to restructure Nigeria's politics and administration. First and foremost, for one to call for restructuring, many dichotomous cum centrifugal forces intermingle and interplay within the ecosystem, which makes the state possess an anti-social and anti-development posture. Undoubtedly, Nigerian federalism has better chances of getting and delivering the dividends of democracy through true federalism anchored upon restructuring if all states and grassroots will begin to restructure their respective political terrain. The logic of restructuring is centered on charity begins at home. That is "if you make your place convenient and I make my own, the whole place will be liveable on earth, and everybody will be happy. If the grassroots and state governors restructure their respective units, restructuring will transcend to the center. Generally, the federating partners in Nigeria must synergically restructure the entire system through the instrumentality of a constitutional rebirth.

Good Condition of Service - Employees in this country have little or no encouraging condition of service. Apart from this, one of the problems faced by Nigerian workers is the problem associated with retirement. Retirement is a period of time where one is not actively engaged in gainful employment where he/she had actively contributed to the goals of that institution over a specific period of time. The fact is that so many employees are unwilling to retire because, at the point of retirement, retirement benefits such as gratuity and pension are not quickly released for the beneficiaries' use. The administration of Governor Ifeanyi Ugwuanyi of Enugu State, Nigeria, has denied the majority of retirees their retirement benefit - gratuity is a worrisome issue. Allegedly, this administration has nepotistically paid retirees who are party loyalists, close associates, and cronies their gratuities upon bowing out of active service - retirement. If the federating units in Nigeria's government environment decide to do the needful, Nigerian federalism has the prospect of changing in this direction.

\section{Conclusion}

Many Nigerians do not have an adequate understanding of the nitty-gritty of federalism. As a corollary to this, destructive tendencies have troubled Nigerian federalism, making the center epileptic. The obvious negative and centrifugal tendencies that have contaminated and made it disastrous in this era have herein been spotted as the challenges of Nigeria's style of federalism. Therefore, this review is adequate to conclude. 


\section{PanAfrican Journal of Governance and Development, Vol. 2, No. 2, August 2021}

There is a huge nexus between federalism and democracy, and in this sense, we predicate that federalism will succeed under a democratic government, and if there is no democracy, then federalism would just be floating like a boat upon the river. Therefore, the challenges pointed out in this review make a mockery of Nigeria on the global scene. Thus, it calls for immediate response by adopting the panacea provided below and other possible means to ameliorate the negative impacts of those challenges on Nigerian federalism.

Having attained the cardinal objectives of this review, there are other unresolved questions thrown up in this review. Hence, this review did not examine any possible impact of Executive Legislative Conflicts on Nigeria Federalism and the way forward. Also, this review did not ascertain the effects of Federal and State Conflicts on Nigeria's Federalism and the measures of mitigating its effects for proper Administration of Nigeria.

\section{Anatomy of Nigerian Federalism: The Panacea}

From a globalized approach, federalism thrives in federalist countries with well-structured cum perceived leadership duties at the center and other federating units. To get it right, we turn attention to the need to install well-meaning leadership in Nigeria's federal system of government from the state to the federal government. Leadership involves responsibility based on a clear perception of areas of functionalities and necessities. It would ordinarily include financial, administrative, and public accountability at all governance/public administration levels. This is achievable when politicians are given their due place in the scheme of things within the Federal Republic of Nigeria.

War against corruption is a step in the right direction. However, as already pointed out, Nigeria is soaked in anti-corruptionist philosophy with its evident utopian approach. Hence, a paradigm shift from existing to the expected is among the way forward. The fight against corruption calls for all hands to be on deck to kill this evil that Nigerians were hurriedly socialized with.

As earlier stated, boundary disputes have brought a loss of lives and properties, a decrease in GDP, per capita income, and a decrease in the nation's economic health. In order to curb the loss of lives occasioned by the problem of boundary disputes, the government should conduct nationwide boundary delimitation.

In short, to overcome the recent problems posed by \#END SARS protests in Nigeria, we must tackle the problem of development within our territorial space, starting from the grassroots States and Federal government. Thus, for Nigerian federalism to be sustained, we need not 
Chioke, Stephen Chinedu, Anatomy of Nigerian Federalism: A Reflection of...

require merely the tissue paper development program but the actual execution of those programs. Implementation of development policies is herein canvassed for as a way out.

To overcome the avalanche of centrifugal forces trying to tear this nation apart aggressively, the federal government should look into the issue of state creation. The southeast geopolitical zone is at the hub of this, as there should be a creation of another state in the southeast to equitably balance the state powers in all the existing geopolitical zones in Nigeria. It is sheer wickedness that other geopolitical zones are made of six states each while the southeast has just five states to her credit.

\section{Implications of the Study}

This review has implications for effective learning and practice by students and politicians. Therefore, with the results on specific objective number one, the researcher discovered that both secondary school and undergraduate students in Nigeria need proper academic support and guidance from educators in charge of teaching 'Government' and 'Political Science' as fields of study because this will provide an atmosphere that is not inimical to the academic development. This review is thus a guide and a reference tool to other scholars and researchers for further researches on the subject matter and related areas.

The other findings implicate that the country called the giant of Africa has continued its federalist operations on the side of very low cohesion and unification of existing ethnic groups. Hence, this review will positively affect policymaking in Nigeria by spurring unifying public policies to be initiated, formulated, and implemented in Nigeria.

\section{Suggestions on Future Direction of Studies}

The following areas are recommended for further empirical study/review:

$>$ An Analysis of the Impact of Stomach Infrastructure on the Development of Electioneering Processes in a Federalist State.

$>$ Federalism: A Comparative Survey of Nigeria and Ghana

Executive - Legislative Conflicts in Nigeria Federalism: An Examination of the Causative Agents and Possible Treatments.

$>$ Effects of Federal and State Conflicts on Nigeria Federalism and the Way Forward

\section{References}

Abdul R. M. (1986). The national question and radical politics in Nigeria. Review of African Political Economy. 13(37): 81-96. 


\section{PanAfrican Journal of Governance and Development, Vol. 2, No. 2, August 2021}

Akpotor, S. A. (1995). The dynamics of federal character in Nigeria: A polity in transition selfreliance, politics and administration in Nigeria. 216.

Amah, E. I. (2017). Federalism, Nigerian federal constitution and the practice of federalism: An appraisal. Beijing Law Review (8): 287-310.

Chikendu, P. N. (2002). Introduction to political science. Enugu: Academy Publishing Company.

Chioke, S. C \& Mbamalu, K. U. (2020). Human resource planning and organizational performance: A philosophical approach. International Journal of Management, Social Sciences, Peace and Conflict Studies (IJMSSPCS). 3(3): 387- 398.

Chioke, S. C (2020a). The trouble with godfatherism in Enugu State from 1999 - 2019: diagnosing the gargantuan enigma and the escape route thereof. Journal of Public Administration and Governance Research. 3(1):277-300.

Chioke, S. C. (2016). The impact of treasury single account on the administration of state and national bureaucracy: A study of Nigerian Immigration Service, Enugu State Command. M.Sc. Thesis submitted to the Department of Administration, Faculty of Management Sciences. National Open University of Nigeria.

Chioke, S. C. (2017). An overview of bureaucracy and treasury single account in an era of economic change. Journal of Research in Science and Technology Education. 7(2):1-13.

Chioke, S. C. (2020b). Corruption and sustainable national development: The underlying implications and overarching consequences. Kobia International Journal of Education Humanities and Social Science 1(1):49-62.

Chioke, S. C. (n.d). Government, politics, and administration in Nigeria and beyond: Past and present issues. Unpublished paper.

Creswell, J. W. (1998). Qualitative inquiry and research design: Choosing among five traditions. California: Sage Publications.

Dauda, B. (2020). Transactional politics: The manifestations of the challenges of infrastructure of the stomach' and 'infrastructure for the stomach' in Nigeria. Journal of Contemporary African Studies. 38(3):366 -380.

Ewuim, N. C. (2008). Succinct approach to government: A comparative analysis. Awka: Mount Carmel Printing \& Publishing Ltd.

Heather, C. (2011). The impact of political corruption on social welfare in the federal republic of Nigeria. Department of Political Science University of Central Florida Orlando, Florida.

Idike, A. N. A. (2014). Democracy and the electoral process in Nigeria: Problems and prospects of the E-Voting Option. Asian Journal of Humanities and Social Sciences (AJHSS). 2(2): 133-141.

Ilufoye, S. O (2009). Political corruption in Nigeria: Theoretical perspectives and some explanations. The Anthropologist 11(4):281-292.

Kalu, O. U (1978). Precarious vision: The African's perception of his world in Kalu, O. U (ed.). Reading in African humanities, African cultural development. Enugu: Fourth Dimension Publishing Co. Ltd, 37 - 44.

Leke, S. (2013). Is Local Government Federating Unit? The Nation Newspaper. June 18, 2013. Retrieved November 2, 2020.

Maduabum, C.P. (2008). The Mechanics of Public Administration. Lagos: Concept Publications Ltd cited in National Open University of Nigeria (NOUN) (2014), course guide on 
Chioke, Stephen Chinedu, Anatomy of Nigerian Federalism: A Reflection of...

"Ecology of public administration" course code: PAD 803, Lagos: National Open University of Nigeria.

Mgbenkemdi, E. H. (2015) Godfatherism: Life and survival in Nigeria society: A psychoanalytic approach. Global Journal of Applied, Management and Social Sciences (GOJAMSS). (9):9-19.

National Open University of Nigeria (NOUN) (2014), course guide on "Ecology of public administration" course code: PAD 803, Lagos: National Open University of Nigeria.

Oboli, H. O. N (1965). Beginning geography in Eastern Nigeria. Ikeja: Longmans, Green \& Co. Ltd.

Ojukwu, C. (1989). Because I am involved. Ibadan: Spectrum Books Ltd.

Okafor, R. C \& Emeka, L. N. (2004). Concept of culture in Okafor, R. C \& Emeka, L. N (eds). Nigerian Peoples and Culture. Enugu: Nigerian Generation Books.

Ola, R. F. (1995). Nigerian political system: Inputs, outputs and environment. Benin City: Ambik Press.

Rotimi, S. (2010). The Nigerian federal system: Performance, problems and prospects. Journal of Contemporary African Studies. 28 (4):459-477.

Sapru, R. K (2013). Administrative theories and management thought (3rd ed). Delhi: PHI Learning Private Limited.

Udenta, J. O. E (2004). The Nigerian perception of his/her world of shibboleths, Manichaeism, colonial mentality. In Okafor, R. C \& Emeka, L. N (eds). Nigerian peoples and culture. Enugu: Nigerian Generation Books.

Ufot, B. I. (1991). Federalism in Nigeria: The crucial dynamics. The Round Table. 80(318): 191207.

Ukeje, I. O. (2006). The challenges of effective leadership in Nigerian public administration: (A case study of Obasanjo administration 1999-2006). Unpublished B.Sc Project). Department of Political Science and Public Administration, Ebonyi State University, Abakaliki, Nigeria. 